\author{
Research Article \\ www.ijrap.net
}

\title{
PHARMACEUTICAL STANDARDIZATION OF ARJUNARISHTA: A BIO-MEDICAL FERMENTED PREPARATION
}

\author{
Akhilesh Kr. Verma ${ }^{1}$, Neeraj Kumar ${ }^{2} *$ L.N. Gupta ${ }^{3}$, Arvind ${ }^{4}$ \\ ${ }^{1} \mathrm{Ph} . D$. Scholar, Department of Rasa Shastra, Faculty of Ayurveda, IMS, BHU, Varanasi, India \\ ${ }^{2}$ Professor, Department of Rasa Shastra, Faculty of Ayurveda, IMS, BHU, Varanasi, India \\ ${ }^{3}$ Assistant Professor, Department of Rasa Shastra, Faculty of Ayurveda, IMS, BHU, Varanasi, India \\ ${ }^{4}$ Assistant Professor, Center of Food Science and Technology, Institute of Agricultural Sciences, BHU, Varanasi, India
}

Received on: 25/07/14 Revised on: 20/08/14 Accepted on: 23/08/14

*Corresponding author

Dr. Neeraj Kumar, Professor, Department of Rasa Shastra, Faculty of Ayurveda, IMS, BHU, Varanasi, India

E-mail: nk.neeraj53@yahoo.in

DOI: $10.7897 / 2277-4343.05498$

\section{ABSTRACT}

Arjunarishta also known as Parthadyarista is an imperative Ayurvedic formulation used for cardiovascular disorders. The aim of this study was to pharmaceutically standardized Arjunarista on the basis of pot and dhataki puspa. Arjunarista was prepared as per sandhana kalpana (Bio-medical fermentation) by using Arjuna twak (Terminalia arjuna), Draksha phala (Vitis vinifera), Madhuka pushpa (Madhuka indica) and jaggery (Saccharum officinarum). Two variation was considered for pharmaceutical standardization of Arjunarista i.e. pot (earthen and porcelain) and Dhataki puspa (addition and deletion). Arjunarista prepared in porcelain pot have higher yield (Batch III 63.29 \%, Batch IV 62.49 \%) than Arjunarista prepared in earthen pot (Batch I $35.05 \%$, Batch II $24.45 \%$ ). Besides this earthen pot as well as porcelain pot without addition of Dhataki puspa comprise higher yield (Batch I $35.05 \%$, Batch III $63.29 \%$ ) in comparison of earthen as well as porcelain pot with addition of Dhataki puspa (Batch II $24.45 \%$, Batch IV $62.49 \%$ ). We found that Dhataki puspa have no role in the fermentation and porcelain pot having higher yield than earthen pot.

Keywords: Arjunarista, Dhataki puspa, Standardization, Bio-medical fermentation.

\section{INTRODUCTION}

This traditional system comprises of various types of medicines including fermented forms, namely, Aristas and Asavas. Aristas are an important group of formulations used in Ayurveda. Arjunarista also known as Parthadyarishta is one of the ancient liquid oral formulations prescribed in Ayurveda for cardiovascular disorders ${ }^{1}$. It nourishes and strengthens heart muscle and promotes cardiac functioning by regulating blood pressure and cholesterol. The ingredients in this formulation are Terminalia arjuna, Madhuca indica, Vitis vinifera, Woodfordia fruticosa and Saccharum officinarum ${ }^{2}$. In vitro and in vivo studies on Terminalia arjuna have shown positive results on cardiovascular disorders ${ }^{3}$. The stem bark of Terminalia arjuna has been used for alleviating angina and other cardiovascular conditions ${ }^{4}$. The extract also improved the symptoms of refractory chronic congestive heart failure ${ }^{5}$. Oral administration of Terminalia arjuna bark also prevented ischemicreperfusion injury induced oxidative stress and tissue injury of heart in rabbits indicating its beneficial therapeutic effect in ischemic heart disease ${ }^{6}$. Arjunolic acid was shown to have protective effect on arsenicinduced myocardial injury ${ }^{7}$. Similarly, the effect of arjunic acid, arjungenin, arjunetin and arjunglucoside II was studied on process of respiratory oxidative burst ${ }^{8}$. Arjunarista is prepared by decoction. Standardization is an important aspect for establishing the quality and efficacy of Ayurvedic formulations or any multiple ingredient herbal formulations. Here an attempt was made to do pharmaceutical standardization of Arjunarista with consideration of pot and Dhataki puspa as a variant.

\section{MATERIALS AND METHOD}

In the present study, two variations were taken in to consideration i.e. pot and Dhataki puspa. In pot variation two types of pot were used i.e. earthen pot and porcelain pot, and in Dhataki puspa, addition and deletion of Dhataki puspa was considered. In this way four batches of Arjunarista were prepared and in each three sample were prepared, thus total number of sample were twelve.

\section{Pharmaceutical study \\ Procurement and Identification}

Fresh Arjuna (Terminalia arjuna) stem bark was collected from BHU campus nearby Dhanwantari Bhawana, Faculty of Ayurveda, IMS, BHU, and Nagarjuna Doctors Hostel BHU, Varanasi, India. Jaggery (Saccharum officinarum) was taken from the home made process by sugar-cane, and rest of the drugs i.e. Draksha (Vitis vinifera), Madhuka (Madhuka indica), Dhataki (Woodfodia fruiticosa) were purchased from the local market of Varanasi, India publically known as Dina Nath Gola market. Identification of all raw materials was done in Dept. of Dravya Guna, Faculty of Ayurveda, IMS, BHU, Varanasi, India.

\section{Pot Preparation}

Washing of Porcelain pot with detergent and rinsing was done then after it was dried in sunlight for $12 \mathrm{~h}$, earthen pot was newly purchase from the market and soaked overnight. Lepana (coating) of Honey and Cow ghee was applied on internal surface of pots. Dhoopana (fumigation) was done along with Guggulu, Karpura, Raal, Sarsapa, Guda. Duration of fumigation was 20 minutes in all pots. Arjuna stem bark was washed 
properly with tap water to avoiding foreign matter as an impurity like dust, sand etc.

\section{Decoction}

Freshly collected stem bark of Arjuna $(20.7 \mathrm{~kg})$ was dried on indirect sunlight for 3-4 days. Weight was taken on electronic weighing machine and it was noted $10.2 \mathrm{~kg}$. Loss on drying: $50 \%$ (Approx). Powder of dried Arjuna bark was prepared in Ayurvedic Pharmacy, IMS, BHU, Varanasi, India. Sieve applied for this purpose was 40 no. within the range of coarse powder. Rest of the drugs was used after ensuring its genuineness and free from impurity. Yavakuta churna (coarse powder) of Arjuna (Terminalia arjuna) stem bark, Draksha (Vitis vinifera) fruit and Madhuka (Madhuka indica) flower were used as a whole in preparation of decoction at mild temperature i.e. $\left(150-250^{\circ} \mathrm{C}\right)$. When kwatha reduced to $1 / 4$ of initial quantity then kwatha was strained with double layered cotton cloth and measured.

\section{Wort Formation}

After straining of kwatha with double folded cotton cloth in another cleaned vessel; jaggery and dhataki puspa was added and dissolved it thoroughly by proper mixing with steel ladle. Finally wort was filled in earthen as well as porcelain pots and placed at proper place. Color of wort was dark brown. Smell of wort was very characteristic, sweet and fruity. Viscosity was higher than kwatha drava. Proper mixing was done to make a homogenous mixture. Jaggery and dhataki puspa was added in decoction after half an hour when temperature reaches to $40-50^{\circ} \mathrm{C}$.

\section{Fermentation Process}

Prepared wort was filled in earthen as well as porcelain pot. These pots were placed in husk and temperature of husk as well as room temperature was recorded during procedure, it was $36^{\circ} \mathrm{C}$ and $35^{\circ} \mathrm{C}-37^{\circ} \mathrm{C}$ respectively. After starting the fermentation process, mouth of pot was sealed with cotton cloth smeared with clay. Whole arrangement was kept and observations were recorded during process. After acquiring the siddhi lakashan (completion test), prepared Arjunarista was filtered with cotton cloth and stored in containers.

\section{Storage and Packaging}

Storage of final product was done in cleaned bottle and sealed it by providing $1 / 3$ vacant space in bottle. Labeling and packaging done as per drugs and cosmetics Rules, 1945 Part - XVII, Rule $161^{9}$.

\section{RESULTS \\ Kwatha}

$6.52,6.25,6.18$ and 6.10 liter kwatha was obtained in I, II, III and IV respectively. (Details are summarized in Table 1)

\section{Wort}

$7.15,7.00,6.90$ and 6.72 liter wort was obtained in I, II, III and IV respectively. (Details are summarized in Table 2)

\section{Fermentation}

Fermentation started at $4^{\text {th }}$ day in all batches except batch II, completion taken place in between 12 - 18 days, maturation were taken place in 7-10 days and total duration taken for fermentation was 22 - 27 days. (Details are summarized in Table 3)

\section{Quantitative Yield of Arjunarista}

Final percentage yield in earthen pot was $33.46 \%$ while in porcelain pot it was $75.0 \%$ which is comparatively very high after deletion of Dhataki puspa the yield in earthen pot (batch I) was $39.76 \%$ while in porcelain pot (batch III) was $80.64 \%$. After addition of Dhataki puspa yield in earthen pot (batch II) was $26.54 \%$ while in porcelain pot (batch IV) it was $69.70 \%$ which is comparatively moderate high. (Details are summarized in Table 4)

\section{DISCUSSION}

Selection of a dosage form depends upon maximum possible extraction of the active components required for therapeutic use. There are several dosage forms in our literature like swaras kalpana, kwatha kalpana, sneha kalpana, sandhan kalpana etc., among these sandhana kalpana (alcoholic dosage form) are the most suited formulations having hydro- alcoholic nature with quick absorption capacity. In arista self generated alcohols produced during process are also proved to be as a better solvent as well as good preservative ${ }^{10}$. Fermentation actively ruptures the cells of the herb, exposing it openly to the menstruum and bacteria have enzymes that break down cell walls to further assist in the leaching process. Fermentation also creates an active transport system that moves the dissolved constituents from the herbal material to the menstruum. Gandha dravyas (aromatic drugs) are commonly used for lepana samsakara along with Ghrita and Madhu. These are attributed for their antimicrobial properties, which may not hamper the activity of required yeast and help in sterilization. All micro-organisms require water, source of energy, carbon, nitrogen, mineral elements and possibly vitamins plus oxygen ${ }^{11}$. Kwatha which was prepared with Arjuna, Draksha and Madhuk is an essential part of Arjunrista; it acts as solvent for the fermentation media and provides water which forms one of the constituents of growth of micro-organism. Microorganisms utilize this appropriate culture media for the production of the primary and secondary metabolite. It is also helpful in the extraction of active constituent of respective herbs. Grapes consist of clear juice (80\%). This juice consists of $79 \%$ water, $20 \%$ carbohydrates, 1 $\%$ organic acids, trace amounts of organic acids, phenolics, vitamins, minerals and nitrogenous compounds $^{12}$. The sugars, organic acids and phenolics of grape juice provide its flavor, while the vitamins, minerals and nitrogenous compounds play essential role for yeast growth and fermentation. The most important sugars in grape juice are the two six-carbon sugars glucose and fructose. These are the sugars that make the juice sweet and are fermented to alcohol. There are many sources of nitrogen in grapes (e.g. DNA, enzymes, inorganic nitrogen etc.) but the most common (and most significant) of these are amino acids. 
Table 1: Details about kwatha preparation

\begin{tabular}{|c|c|c|c|c|}
\hline Parameters & Batch I & Batch II & Batch III & Batch IV \\
\hline Kwatha dravya & $4.080 \mathrm{Kg}$. & $4.080 \mathrm{Kg}$. & $4.080 \mathrm{Kg}$. & $4.080 \mathrm{Kg}$. \\
\hline Water & $24 \mathrm{~L}$ & $24 \mathrm{~L}$ & $24 \mathrm{~L}$ & $24 \mathrm{~L}$ \\
\hline Reduced up to & $1 / 4^{\text {th }}$ & $1 / 4^{\text {th }}$ & $1 / 4^{\text {th }}$ & $1 / 4^{\text {th }}$ \\
\hline Maximum Temp & $102^{0} \mathrm{C}$ & $100^{0} \mathrm{C}$ & $103^{0} \mathrm{C}$ & $101{ }^{0} \mathrm{C}$ \\
\hline Duration & $8.45 \mathrm{~h}$ & $10.10 \mathrm{~h}$ & $9.14 \mathrm{~h}$ & $8.30 \mathrm{~h}$ \\
\hline Yield & $6.54 \mathrm{~L}$ & $6.25 \mathrm{~L}$ & $6.18 \mathrm{~L}$ & $6.10 \mathrm{~L}$ \\
\hline
\end{tabular}

Note: Kg.: Kilogram, L: Liter, ${ }^{\circ}$ c: Degree Centigrade, h: Hour

Table 2: Details about wort preparation

\begin{tabular}{|c|c|c|c|c|}
\hline Parameters & Batch I & Batch II & Batch III & Batch IV \\
\hline Kwatha & $6.54 \mathrm{~L}$ & $6.25 \mathrm{~L}$ & $6.18 \mathrm{~L}$ & $6.10 \mathrm{~L}$ \\
\hline Dhataki & $480 \mathrm{~g}$. & $480 \mathrm{~g}$. & $480 \mathrm{~g}$. & $480 \mathrm{~m}$. \\
\hline Jaggery & $2.4 \mathrm{Kg}$. & $2.4 \mathrm{Kg}$ & $2.4 \mathrm{Kg}$ & $2.4 \mathrm{Kg}$ \\
\hline Yield (L) & $7.15 \mathrm{~L}$ & $7.00 \mathrm{~L}$ & $6.90 \mathrm{~L}$ & $6.72 \mathrm{~L}$ \\
\hline
\end{tabular}

Note: g: gram, L: Liter, Kg: Kilogram

Table 3: Details about fermentation process regarding duration

\begin{tabular}{|c|c|c|c|c|}
\hline Fermentation & Batch I & Batch II & Batch III & Batch IV \\
\hline Starting day & $4^{\text {th }}$ & $5^{\text {th }}$ & $4^{\text {th }}$ & $4^{\text {th }}$ \\
\hline Completion day & 15 day & 12 day & 18 day & 17 day \\
\hline Maturation day & 8 day & 10 day & 7 day & 10 day \\
\hline Total duration & 23 day & 22 day & 25 day & 27 day \\
\hline
\end{tabular}

Table 4: Details about yield of Arjunarista

\begin{tabular}{|c|c|c|c|c|}
\hline Parameters & Batch I & Batch II & Batch III & Batch IV \\
\hline Total wort & $7.150 \mathrm{~L}$ & $7.000 \mathrm{~L}$ & $7.900 \mathrm{~L}$ & $6.700 \mathrm{~L}$ \\
\hline Yield & $2.505 \mathrm{~L}$ & $1.712 \mathrm{~L}$ & $5.006 \mathrm{~L}$ & $4.287 \mathrm{~L}$ \\
\hline Percentage (\%) & $35.05 \%$ & $24.45 \%$ & $63.29 \%$ & $62.49 \%$ \\
\hline
\end{tabular}

Note: L: liter, \%: percentage

Table 5: General observation of fermentation process of wort of all batches

\begin{tabular}{|c|c|c|c|c|c|c|c|c|c|c|c|c|c|c|c|c|c|}
\hline \multirow{2}{*}{\multicolumn{2}{|c|}{ Para }} & \multicolumn{4}{|c|}{ Batch I Fermentation } & \multicolumn{4}{|c|}{ Batch II Fermentation } & \multicolumn{4}{|c|}{ Batch III Fermentation } & \multicolumn{4}{|c|}{ Batch IV Fermentation } \\
\hline & & $\mathrm{D}$ & Sta & Dur & $\mathrm{Aft}$ & $\mathrm{D}$ & Sta & Dur & $\mathrm{Aft}$ & $\mathrm{D}$ & Sta & Dur & $\mathrm{Aft}$ & $\mathrm{D}$ & Sta & Dur & Aft \\
\hline \multicolumn{2}{|c|}{ Colo } & DB & DB & DB & DB & DB & DB & DB & DB & DB & D.B & D.B & D.B & DB & DB & DB & DB \\
\hline \multicolumn{2}{|c|}{ Smell } & $\mathrm{S} / \mathrm{f}$ & $\mathrm{S} / \mathrm{f}$ & $\mathrm{V} / \mathrm{A}$ & $\mathrm{V} / \mathrm{A}$ & $\mathrm{S} / \mathrm{f}$ & $\mathrm{S} / \mathrm{f}$ & $\mathrm{V} / \mathrm{A}$ & $\mathrm{V} / \mathrm{A}$ & $\mathrm{S} / \mathrm{f}$ & $\mathrm{S} / \mathrm{f}$ & $\mathrm{V} / \mathrm{A}$ & $\mathrm{V} / \mathrm{A}$ & $\mathrm{S} / \mathrm{f}$ & $\mathrm{S} / \mathrm{f}$ & $\mathrm{V} / \mathrm{A}$ & $\mathrm{V} / \mathrm{A}$ \\
\hline \multirow[t]{3}{*}{ T. } & A & ++ & ++ & ++ & ++ & ++ & ++ & ++ & ++ & + & + & + & + & + & + & + & ++ \\
\hline & $\mathrm{Sw}$ & ++ & ++ & - & - & ++ & ++ & - & - & ++ & ++ & + & - & ++ & ++ & - & - \\
\hline & So & - & - & ++ & +++ & - & - & ++ & +++ & - & - & + & + & - & - & + & ++ \\
\hline \multicolumn{2}{|c|}{ Sound } & - & - & + & - & - & - & + & - & - & - & + & - & - & - & + & - \\
\hline \multicolumn{2}{|c|}{ Eff. } & - & - & + & - & - & - & + & - & - & - & + & - & - & - & + & - \\
\hline \multicolumn{2}{|c|}{ BMST } & - & - & + & - & - & - & + & - & - & - & + & - & - & - & + & - \\
\hline \multicolumn{2}{|c|}{ L.W.T } & - & - & + & - & - & - & + & - & - & - & + & - & - & - & + & - \\
\hline \multicolumn{2}{|c|}{ Temp } & RT & RT & Rais. & RT & RT & RT & Rais & RT & RT & RT & Rais & RT & RT & RT & Rais & RT \\
\hline \multicolumn{2}{|c|}{ Consisten. } & ++ & ++ & + & + & ++ & ++ & + & + & ++ & ++ & + & + & ++ & ++ & + & + \\
\hline
\end{tabular}

Note: Para.: parameter, D.: 0 day, Sta.: starting day, Dur.: during fermentation, Aft.: after fermentation, Colo.: color, DB.: dark brown, S/f: sweet/fruity, V/A: vinegar/alcoholic, A: astringent, T: taste, Sw: sweet, So: sour, Sound: hissing sound, Eff.: effervescent,

BMST: burning match stick test, L.W.T.: lime water test, Temp: temperature, Consisten.: consistency, RT: room temperature, Rais.: raised,,,++++++ : showing increasing grading sequence

As free amino acids are important building blocks for fermentation. The most important minerals are magnesium and potassium, which are important in fermentation, and phosphate, which is necessary for growth of micro- organism. Nitrogen addition during fermentation of grape must increases fermentation rate ${ }^{13}$. Mahua flowers contains $65-70 \%$ sugars, reducing sugars 48-55 \%, Invert sugar 14-18, crude protein 4.0-6.5, ferrous $21-48 \%$ fat $0.9-1.3$, ash $2.5-5.2 \%$ and calcium $177-266 \%{ }^{14}$. It is reported that Mahua flower help in the fermentation process ${ }^{15}$. This might be reason for addition of its flowers. Mahua is also suitable substrate for the production of ethanol in large scale process, because it consists of phosphorous of about $140 \mathrm{mg}$, Calcium 150 mg, Magnesium and Copper are also present ${ }^{16}$. Concentration of madhura dravya play important role for fermentation as well as the quality of yield product. Although the percentage of total sugar content in jaggery found to be in the range of $60-80 \%$ only; increases the concentration of sugar in liquid media restricting the growth of organisms required action. Sugar used in the Arjunarista provides optimum concentration of sugar required for fermentation process. The use of Dhataki puspa as a fermenter is expounded with research carried 
out through identification of micro-organism Sacchromyces cervisicae in Dhataki puspa (Woodfordia fruticosa). Time and Temperature plays critical role in the breakdown of sugar. Optimum range of temperature and time fit for breakdown of sugar is between $74-84{ }^{0} \mathrm{~F}$ (21-29 ${ }^{0} \mathrm{C}$ ) and 8-14 days. Arjunarista was prepared in summer season at environmental temperature ranging from $34-37^{\circ} \mathrm{C}$ and total time taken for completion of process was 15 days (average). Sound was perceived when the reaction was started and glucose molecule gets converted in to ethanol and $\mathrm{CO}_{2}$ gas due to chemical reaction. This reaction lay down with the help of microorganism i.e. mostly of Cerevisiae sp., now this $\mathrm{CO}_{2}$ evolve from liquid media produced hissing sound. When sound stopped this denotes completion of process, if this is passed through lime water it get converted into turbid due to formation of $\mathrm{CaCO}_{3}$ compound which also indicate that the process is going on. During the process of fermentation $\mathrm{CO}_{2}$ release and there was absence of $\mathrm{O}_{2}$ gas which can be confirmed with test in which burning of match stick get extinguish. Absence of hissing sound, unable to change lime water color and burning of match stick denote the completion of process that indicate $\mathrm{CO}_{2}$ was not released in the fermentation anymore. Quantity of Arjunarista obtained in batches having Dhataki puspa as fermenter was less in comparison to batches without Dhataki puspa; it may be due to soaking of some quantity of Arjunrista by Dhataki puspa. Arjunarista prepared in earthen pot was found to have lesser yields than porcelain pot. Earthen pot is having greater porosity than porcelain pot which is almost non porous. Due to presence of porosity in earthen pot, evaporation of Arjunarista takes place which reduces the yield of Arjunarista. Self generated alcohol is prepared during the process. It may probably be due to the results of transformation of several phytochemical compounds present in the herbs. This self generated alcohol possess preservative properties and potentiating of drug due to biotransformation mediated by native microbes, thereby rendering them either less toxic or more potent, besides helping in their rapid absorption ${ }^{17}$.

\section{CONCLUSION}

In this pharmaceutical study, we found that Arjunarista prepared in porcelain pot had higher yield than Arjunrista prepared in earthen pot. Besides this earthen pot as well as porcelain pot without addition of Dhataki puspa showed higher yield in comparison to earthen as well as porcelain pot with addition of Dhataki puspa.

\section{REFERENCES}

1. Dwivedi S. Wight and Arn. A useful drug for cardivascular disorders. Terminalia arjuna, J Ethnopharmacol 2007; 114: 114129. http://dx.doi.org/10.1016/j.jep.2007.08.003

2. Kaviraj Shri Ambikadatta Shastri, Bhaisajya Ratnavali, $19^{\text {th }}$ Edition, Chaukhamba Sanskrita Sansthan, Varanasi; 2008.

3. Dwivedi S. Wight and Arn. - A useful drug for cardivascular disorders. Terminalia arjuna, J Ethnopharmacol 2007; 114: 114129. http://dx.doi.org/10.1016/j.jep.2007.08.003

4. Bharani A, Ganguli A, Mathur LK, Jamra Y, Raman PG. Efficiency of in chronic stable angina: a double-blind, placebo-controlled, cross over Terminalia arjuna study comparing with isosorbide mononitrate. Terminalia arjuna Indian Heart J; 2002.

5. Bharani A, Ganguli A, Bhargava K. Salutary effect of in patients with severe refractory heart failure. Terminalia arjuna Int J Cardiol 1995; 49: 191-199. http://dx.doi.org/10.1016/0167-5273(95)02320$\mathrm{V}$

6. Gauthaman K, Banerjee SK, Dinda AK, Ghosh CC, Maulik SK. (Roxb.) protects rabbit heart against ischemic-reperfusion injury: role of antioxidant Terminalia arjuna enzymes and heat shock protein. J Ethnopharmacol 2005; 96: 403-409. http://dx.doi.org/ 10.1016/j.jep.2004.08.040

7. Manna GK, Banerjee SK, Dinda AK, Ghosh CC, Maulik SK Protects rabbit heart against ischemic-reperfusion injury: role of antioxidant Terminalia arjuna enzymes and heat shock protein. J Ethnopharmacol 2005; 96: 403-409. http://dx.doi.org/ 10.1016/j.jep.2004.08.040

8. Pawar RS, Bhutani KK. Effect of oleanane triterpenoids from a cardio protective drug on the process of Terminalia arjuna respiratory oxyburst. Phytomedicine 2005; 12: 391-393. http://dx.doi.org/10.1016/j.phymed.2003.11.007

9. Malik V. The Drugs and Cosmetics Act 1940, XVIII Edition Eastern Book Company Lucknow; 2005.

10. Handa SS. Extraction Technologies for Medicinal and Aromatic Plants, International centre for science and high technology Trieste; 2008.

11. http://www.assignmenthelp.net/assignment help/media-forindustrial-fermentations.php

12. Heather Wansbrough, chemistry in winemaking, vi-food-b-wine-5

13. Arrizon J, Gschaedler A. Increasing fermentation efficiency at high sugar concentrations by supplementing an additional source of nitrogen during the exponential phase of the tequila fermentation process. Can. J. Microbiol 2002; 48.

14. Sutaria PB, Magar NG. Preparation of sugar analysis of flowers from various districts. Indian Chem. Soc 1955; 18: 75-80.

15. Yadav P, Garg N, Diwedi DH. Effect of location of cultivar, Fermentation temperature and additives in the physic-chemical and sensory qualities on mahua (Madhuka indica JF Gmel) wine preparation. Natural product radiance 2009; 8: 406-418.

16. Mandal P, Kathale N. Production of ethanol from mahua flower (Madhuka latifolia) using Saccharomyces cerevisiae 3044 and study of parameters while fermentation; Vol 1(9).

17. Chaudhary A, Singh N, Dalvi M, Wele A. A progressive review of Sandhana kalpana (Biomedical fermentation): An advanced innovative dosage form of Ayurveda, AYU 2011; 32(3): 408-417. http://dx.doi.org/10.4103/0974-8520.93925

\section{Cite this article as:}

Akhilesh Kr. Verma, Neeraj Kumar, L.N. Gupta, Arvind. Pharmaceutical standardization of Arjunarishta: A bio-medical fermented preparation. Int. J. Res. Ayurveda Pharm. 2014;5(4):476-479 http://dx.doi.org/10.7897/2277-4343.05498 